\title{
Environmental information disclosure and firm performance
}

\author{
Hsuehen Hsu ${ }^{1,}{ }^{*}$ \\ ${ }^{1}$ The International College, Xiamen University, \\ Kunluan Building, Xiang's South Road, Xiamen, China \\ hsuehen@xmu.edu.cn \\ ${ }^{*}$ Corresponding author
}

\begin{abstract}
This study investigates the association of environmental information disclosure and corporate financial performance for the steel industry. This study uses A-share steel industry listed companies in Shanghai Stock Exchange from 2010 to 2014. The environmental information disclosure includes environmental financial and non-financial information. The result shows that there is a negative association between environmental financial disclosure and firm performance. This study also finds no association between environmental non-financial disclosure and firm performance. Environmental non-financial disclosure is more difficult to be quantified and therefore has no effect on enterprise financial performance.
\end{abstract}

Keywords: Environmental information disclosure; Firm performance; Steel industry

\section{Introduction}

With the ecological environment problem getting more attention in the world, the Chinese government also has issued several regulations related to environmental protection regulations. However, the disclosure of environment information is not compulsory. The main disclosure of environmental information for the enterprise depends on voluntary.

There have been a growing number of companies from different industries disclosing their environmental information in their annual reports. Especially, the number of environmental information disclosure studies in China has been increasing(Zeng et al. 2010; Zeng et al. 2011) [1] [2] . This study investigates the association between the environmental information disclosure and firm performance by using the samples of A-share steel industry within the Chinese context. The result shows that there is a negative association between environmental financial disclosure and firm performance. However, this study finds no association between environmental non-financial disclosure and firm performance.

\section{Literature Review}

Stanwick and Stanwick (2000) [3] inspected the relationship between environmental disclosure and financial performance from 469 large corporations listed in the 1994 Forbes 500. The results demonstrated that corporations categorized as high financial performers had higher occurrences of environmental policies and /or environmental commitment than corporations categorized as low performers. In addition, corporations categorized as medium financial performers also had the highest occurrences of firm environmental policies and/or environmental commitment.

Huang and Kung (2010) [4] investigated stakeholder expectations associated with corporate environmental disclosure from 759 Taiwanese firms listed on the Taiwan Stock Exchange. The influences of stakeholders are classified as external, internal, and intermediary stakeholder groups. External stakeholder groups consist of the government, debtors, and consumers. Internal stakeholder groups refer to shareholders and employees. Intermediary stakeholders include environmental protection organizations and accounting firms. The result showed that external stakeholders have strong influences for managements to disclose environmental information and internal stakeholder groups impressed some pressures on firms to disclose environmental information. Additionally, 
intermediate stakeholder group can greatly influence managerial choices for environmental disclosure strategies.

Meng, Zeng and Tam (2013) [5] investigated the relationship between economic performance and Environmental Information Disclosure (EID) for 792 Chinese companies in 2006, 784 in 2007, and 784 in 2008 firms. They also examined how the relationship is affected by the type of ownership from voluntarism to regulation. The empirical results indicated that the relationship between EID and firms performance is compounded and the ownership is an important institutional characteristic influencing EID from voluntarism to regulation in China. Their finding also suggested that the evaluation of corporate EID is associated with economic performance and need to be cautious with the form of ownership from voluntarism to regulation.

Vasanth, Lingaraja and Ramkumar (2015) [6] examined the association between environmental performance and profitability by using a sample of 191 companies from BSE-500 index. The environmental performance was measured by energy intensity ratio. The financial performance was measured by Return on Asstets (ROA), Return on Equity (ROE), Return on Capital Employed (ROCE) and Return on Sales (ROS). The results found that there is a positive relationship between environmental performance and ROA, ROE and ROS.

Chang (2015) [7] examined the relationship of environmental information and tendency disclosure on financial performance by suing the sample size of 139 companies from eight heavy pollution sectors in China. The environmental information disclosure was calculated by environmental disclosure index. The financial performance was calculated by Tobin's Q. The result showed that environmental performance disclosure has a significant influence on Tobin's Q.

\section{Environmental information disclosure and firm performance}

The environmental information disclosure includes environmental financial and non-financial information disclosure. The environmental financial disclosure reflected in monetary terms regarding the environmental investment, costs and provisions. The environmental non-financial information disclosure refers to environmental objectives, management, and policy. Previous studies examining the relationship between environmental information disclosure and firm performance and the result showed that a high disclosure of environmental information can benefit the financial performance of the firm (Neu et al., 1998; Cormier and Magnan, 1999; Prencipe, 2004) [8] [9] [10]. It can be expected that firms incorporate environmental awareness in their operations to gain the potential financial benefits that may occur. Therefore, an environmental policy will influence the actions of the managers of the firms and increase their financial performance (Stanwick \& Stanwick , 2000) [3]. This expectation leads to the following hypothesis:

H1a: There is a positive relationship between environmental financial disclosure and financial performance

H1b: There is a positive relationship between environmental non-financial disclosure and financial performance

\section{Data and Methodology}

The sample consists of 68 A-share steel industry listed companies in Shanghai Stock Exchange from 2010 to 2014. The environmental information disclosure collected from annual financial report, sustainable development report, and social responsibility report. Annual financial data was collected from a leading research database in China, the CSMAR database.

The association between the environmental financial disclosure and non- financial disclosure, and the explanatory variables listed as follows. 
$\mathrm{ROE}=\alpha 0+\alpha 1 \mathrm{EFD}+\alpha 2$ Lnsize $+\alpha 3$ Lev $+\alpha 4$ Growth $+\varepsilon$ (1)

$\mathrm{ROE}=\alpha 0+\alpha 1 \mathrm{ENFD}+\alpha 2$ Lnsize $+\alpha 3 \mathrm{Lev}+\alpha 4$ Growth $+\varepsilon$ (2)

Where

$\mathrm{ROE}=$ Net profit after tax/ Shareholder's equity.

$\mathrm{EFD}=\mathrm{A}$ score of total environmental financial disclosure.

$\mathrm{END}=\mathrm{A}$ score of total environmental non- financial disclosure.

Lnsize $=$ Natural log of total assets

Lev $=$ Total liabilities $/$ total assets

Growth $=\left(\right.$ Sales $_{t}-$ Sales $\left._{t-1}\right) /$ Sales $_{t}$

\section{Empirical results}

The table 1 reports the means, standard deviation among the variables used in the analysis. The average (Std. Deviation) of return on equity (ROE) is 0.97 (28.78). The mean percentage of environmental financial disclosure (EFD) is 4.72 and Std. Deviation is 2.61. The mean percentage of environmental non-financial disclosure (END) is 7.37 and Std. Deviation is 4.85 . The table 2 reports the regression results for the environmental financial disclosure on ROE. The table 3 reports the regression results for the environmental non- financial disclosure on ROE.

Table 1 Descriptive statistics

\begin{tabular}{lllll}
\hline & Minimum & Maximum & Mean & Std. Deviation \\
\hline ROE & -235.73 & 76.11 & .97 & 28.78 \\
EFD & 0 & 10 & 4.72 & 2.61 \\
END & 0 & 18 & 7.37 & 4.85 \\
Lnsize & 18.88 & 26.17 & 23.09 & 1.86 \\
Lev & 17.36 & 124.99 & 68.88 & 18.72 \\
Growth & -99.13 & 617.52 & 13.73 & 66.50 \\
\hline
\end{tabular}

Table 2 The regression results for the environmental financial disclosure on ROE.

\begin{tabular}{lrrl}
\hline & \multicolumn{1}{l}{$\mathrm{t}$} & $\mathrm{p}$ \\
\hline (Constant) & -22.44 & -0.67 & 0.500 \\
EFD & -2.69 & -2.61 & $0.010^{* *}$ \\
Lnsize & 2.84 & 1.94 & $0.054^{* *}$ \\
Lev & -0.45 & -3.66 & $0.000^{* *}$ \\
Growth & 0.11 & 3.00 & $0.003 * *$
\end{tabular}

$* * 0.05$ level of significance

Table 3 The regression results for the environmental non- financial disclosure on ROE.

\begin{tabular}{llcl}
\hline & $\beta$ & $\mathrm{t}$ & $\mathrm{p}$ \\
\hline (Constant) & -17.58 & -0.48 & 0.631 \\
END & -0.94 & -1.47 & 0.144 \\
Lnsize & -2.45 & 1.47 & 0.143 \\
Lev & -0.47 & -3.75 & $0.000^{* *}$ \\
Growth & 0.11 & 2.95 & $0.004 * *$
\end{tabular}

**0.05 level of significance 


\section{Conclusions}

This study explores the correlation of environmental information disclosure and corporate financial performance for the steel industry. This study uses 68 A-share steel industry listed companies in Shanghai Stock Exchange from 2010 to 2014. The environmental information disclosure includes environmental financial and non-financial information. Contrary to previous results, this study shows that there is a negative association between environmental financial information disclosure and firm performance. This indicates that environmental financial disclosure for steel industry is still on the developing stage. Therefore, environmental financial disclosure has a negative impact on financial performance. This study also finds no association between environmental non-financial information disclosure and firm performance. Environmental non-financial disclosure is more difficult to be quantified and therefore has no effect on enterprise financial performance. The limitation of this paper is data only collected from the steel industry. Extending to more industries would provide more perceptive of the relationship between those variables. 
References

[1] S. X. Zeng, , X. D. Xu , Z. Y Dong, \& V. W. Y.Tam: Towards corporate environmental information disclosure: An empirical study in China. Journal of Cleaner Production, Vol 18(12) (2010), p.1142-1148.

[2] S. X Zeng, X. D Xu, H. T.Yin, , C. M.Tam: Factors that drive Chinese listed companies in voluntary disclosure of environmental information. Journal of Business Ethics, Vol 109(3) (2011), p.309-321.

[3] S. D. Stanwick and P. A. Stanwick: The relationship between environmental disclosures and financial performance: An empirical study of US firms. Eco-Management and Auditing, Vol. 7 (2000), p. 155-164

[4] C. Huang and F. Kung: Drivers of Environmental Disclosure and Stakeholder Expectation: Evidence from Taiwan, Journal of Business Ethics Vol.96 (2010) , p.435-45

[5] X. H. Meng , S. X. Zeng and C. M. Tam: From Voluntarism to Regulation: A Study on Ownership,Economic Performance and Corporate Environmental Information Disclosure in China. Journal of Business Ethics Vol.116 (2013), P217-232

[6] V. Vasanth, M. S. Lingaraja and R. R. Ramkumar : Nexus Between Profitability and Environmental Performance of Indian Firms: An Analysis with Granger Causality International Journal of Energy Economics and Policy Vol. 5( 2) (2015), p. 433-439.

[7] K. Chang: The Impacts of Environmental Performance and Propensity Disclosure on Financial Performance: Empirical Evidence from Unbalanced Panel Data of Heavy Pollution Industries in China Journal of Industrial Engineering and Management Vol 8(1) (2015), p.21-36

[8] D. Neu , H. Warsame and K. Pedwell,. Managing public impressions: Environmental disclosures in annual reports. Accounting, Organizations and Society, 23(3) (1998), p.265-282

[9] D. Cormier and M. Magnan. Corporate environmental disclosure strategies: Determinants, costs and benefits. Journal of Accounting, Auditing \& Finance, 14(4) (1999),p. 429-451.

[10] A. Prencipe: Proprietary costs and determinants of voluntary segment disclosure: Evidence from Italian listed companies. European Accounting Review, 13(2) (2004),P. 319-340. 